\title{
Variations of the Vocal Fold Epithelium in a Menopause Induced Model
}

\author{
Variaciones del Epitelio del Pliegue Vocal en un Modelo de Menopausia Inducida
}

"Patricia Oyarzún; "Alfredo Sepúlveda; "María Valdivia; *Ignacio Roa; ***Mario Cantín;

**,***** Gonzalo Trujillo; ${ }^{* * * * * *}$ Daniela Zavando \& **Iván Suazo Galdames

OYARZÚN, P.; SEPÚlVEDA, A.; VALDIVIA, M.; ROA, I.; CANTÍN, M.; TRUJILlO, G.; ZAVANDO, D. \& SUAZO, G. I. Variations of the vocal fold epithelium in a menopause induced model. Int. J. Morphol., 29(2):377-381, 2011.

SUMMARY: During menopause, changes occur in the laryngeal structures that have implications for the voice. The purpose of this study was to determine the effect of induced menopause on the morphological parameters of the vocal fold mucosa in rats. Ten adult female Sprague-Dawley rats were used as samples and divided into two groups: 5 were surgically oophorectomized (OVX), and 5 underwent a surgical procedure similar to oophorectomy but without removal of the ovaries (SHAM). After 30 days surgery, the characteristics of the epithelium that forms the vocal fold mucosa in terms of cellular arrangement and organization of the epithelium were observed. Through the Morphometrics XS software, the epithelial height and the number and density of cellular layers were determined. Our results indicate that there were alterations in the number of cell layers that constitute the epithelium, as well as features, such as cellular cohesion and increased extracellular matrix. The number of cell layers was significantly higher ( $<$ 0.01) in the SHAM group with 6.66 (SD 1.07), whereas in the OVX was 3.2 (SD 0.83). The average thickness of the epithelium was $534.71 \mathrm{~mm}$ (SD 119.89), whereas in the SHAM group was 486.84 $\mathrm{mm}(\mathrm{SD} 82.95)$; these differences were not statistically significant $(\mathrm{p}=0.112)$. Changes in the characteristics of the epithelium covering the vocal folds can be related to clinical abnormalities, such as reduced voice quality and degeneration of the vocal folds in postmenopausal women.

KEY WORDS: Fold vocal; Voice; Menopause; Oophorectomy.

\section{INTRODUCTION}

Menopause is a period in the life of a woman when her body produces less estrogen and progesterone, the ovaries stop producing eggs, and menstruation becomes less frequent until the occurrence of a definite term (Storck et al., 2009). Menopause is accompanied by various signs, such as dyspnea, peripheral vasodilation, sweating, and psychological symptoms such as irritability, insomnia, headaches, fatigue, anxiety, and sometimes depression (Cingolani et al., 2008). In the long term, hypertrophy of the mucosa, decreased vaginal lubrication, osteoporosis, and cardiovascular diseases occur (Mayo, 1999). Alterations of the laryngeal structures, which modify the quality and vocal characteristics, are described along with the above-mentioned changes.

In clinical terms, in postmenopausal women, there is a reduction of phonatory control which causes a decrease in fundamental frequency, low intensity and voice quality, vo- cal fatigue, loss of the higher tones, an increase toward the bass tessitura, thickened ring, and resonance pectoral dominance. Phonatory abnormalities are related to intrinsic muscle atrophy, with decreased mobility of the cricothyroid joint and edema of the mucosa in the vocal folds. However, there is no clarity about the changes experienced by the epithelium of the laryngeal mucosa or its participation in the clinical phenomena observed (Delgado, 2001; Torres, 2007; Gutiérrez, 2003).

Considering the ethical aspect and feasibility, the use of animal models of menopause is a viable option, with oophorectomy in rats as an appropriate model. With the foregoing background, the objective of this research was to determine the effect of induced menopause on morphological parameters of the mucosal epithelium of the vocal folds in an animal model of menopause.

* Escuela de Fonoaudiología, Universidad de Talca, Chile.

** Departamento de Ciencias Básicas Biomédicas, Universidad de Talca, Chile.

**** Universidad de La Frontera, Chile

***** Programa de Magister en Morfología, Universidad de La Frontera, Chile.

****** Universidad Autónoma de Chile, Chile. 


\section{MATERIAL AND METHOD}

Animals. We analyzed 10 adult female Sprague-Dawley rats (Rattus norvergicus), obtained from the Central Vivarium of the Faculty of Medicine, Universidad de Chile. The animals had a period of adjustment to the facility at the Universidad de Talca, where the research was conducted. Conditions, such as health and diet, were evaluated daily. The rats received standard food and water ad libitum throughout the experiment. The temperature, light, and humidity were controlled (temperature $21+2^{\circ} \mathrm{C}$, light-dark cycle of 12 hours, $60+10 \%$ humidity). The maintenance and study protocol was approved by the Bioethics Committee of the Universidad de Talca, Chile.

The procedures for handling animals were conducted in accordance with the recommendations in "Guide for Care and Use of Laboratory Animals" published by U.S. National Institutes of Health (NIH Publication no. 85-23, revised in 2010; http://grants.nih.gov/grants/OLAW /olaw.htm).

The rats were randomized into two groups and anesthetized with ketamine $(50 \mathrm{mg} / \mathrm{kg})$ and xylazine $(10$ $\mathrm{mg} / \mathrm{kg}$ ) intraperitoneally, and preoperative aseptic procedures were performed with the following interventions:

Ovariectomy group (OVX): 5 animals were surgically oophorectomized. The ovaries were clamped bilaterally and removed according to the technique described by Santos et al. (2004).

SHAM control group (SHAM): 5 rats underwent SHAM procedure, where the ovaries were exposed bilaterally and then repositioned.

Procedure. Thirty days after surgery, the animals were euthanized by cervical dislocation, and the vocal folds were immediately dissected under a stereomicroscope (X10). The vocal folds obtained were fixed in modified Millonig formalin by Carlson (pH 7.2 and 0.1 M phosphate buffer) (Sheehan \& Hrapchack, 1980), processed, and placed in Paraplast Plus (Sigma®). Then, $7-\mu$ m-thick serial histological slides were obtained, stained with hematoxylin-eosin, and examined under a Trinocular Olympus CX21 microscope (x40).

Variables. The cellular arrangement on the number of cell layers and epithelial organization based on the presence of rete ridges and cell morphology was analyzed. The cell layers and epithelial height were measured by means of software Morphometrics XS.

Morphologic parameters were described in the OVX and SHAM groups. For the quantitative parameters, descriptive statistics was used, and the means were compared using $t$ test with $\mathrm{p}<0.01$.

\section{RESULTS}

The variable number of cell layers and thickness of vocal folds are shown in Table I. In the qualitative analysis of the vocal folds, the SHAM group was observed to show a typical epithelium to the vocal folds, nonkeratinized stratified squamous without rete ridges; epithelial cells showed characteristic morphology that flattens as they approach the surface. The number of cell layers was 5 to 8. (Fig. 1).

The OVX group showed a typical epithelium to the vocal folds, nonkeratinized stratified squamous with rete ridges, unlike the previous group. Some epithelial cells in the superficial layers had rounded nuclear morphology. In contrast to the SHAM group; it was not possible to observe the cell nuclei in the most superficial layer. The number of cell layers was found to decrease from 2 to 5 layers. (Fig. 2).

Table I. Descriptive statistics for the parameters number of cell layers and thickness of vocal folds epithelium in groups of rats oophorectomized and SHAM.

\begin{tabular}{|c|c|c|c|c|c|}
\hline & \multicolumn{2}{|c|}{ OVX } & \multicolumn{2}{|c|}{ SHAM } & \multirow[b]{2}{*}{$\mathbf{p}$} \\
\hline & Mean & SD & Mean & SD & \\
\hline Numbers of cell layers & 3.20 & 0.83 & 6.66 & 1.07 & $\mathrm{p}<0.01$ \\
\hline Thickness of vocal folds epithelium & $534.7 \mu \mathrm{m}$ & 119.89 & $486.84 \mu \mathrm{m}$ & 82.95 & $\mathrm{p}=0.112$ \\
\hline
\end{tabular}




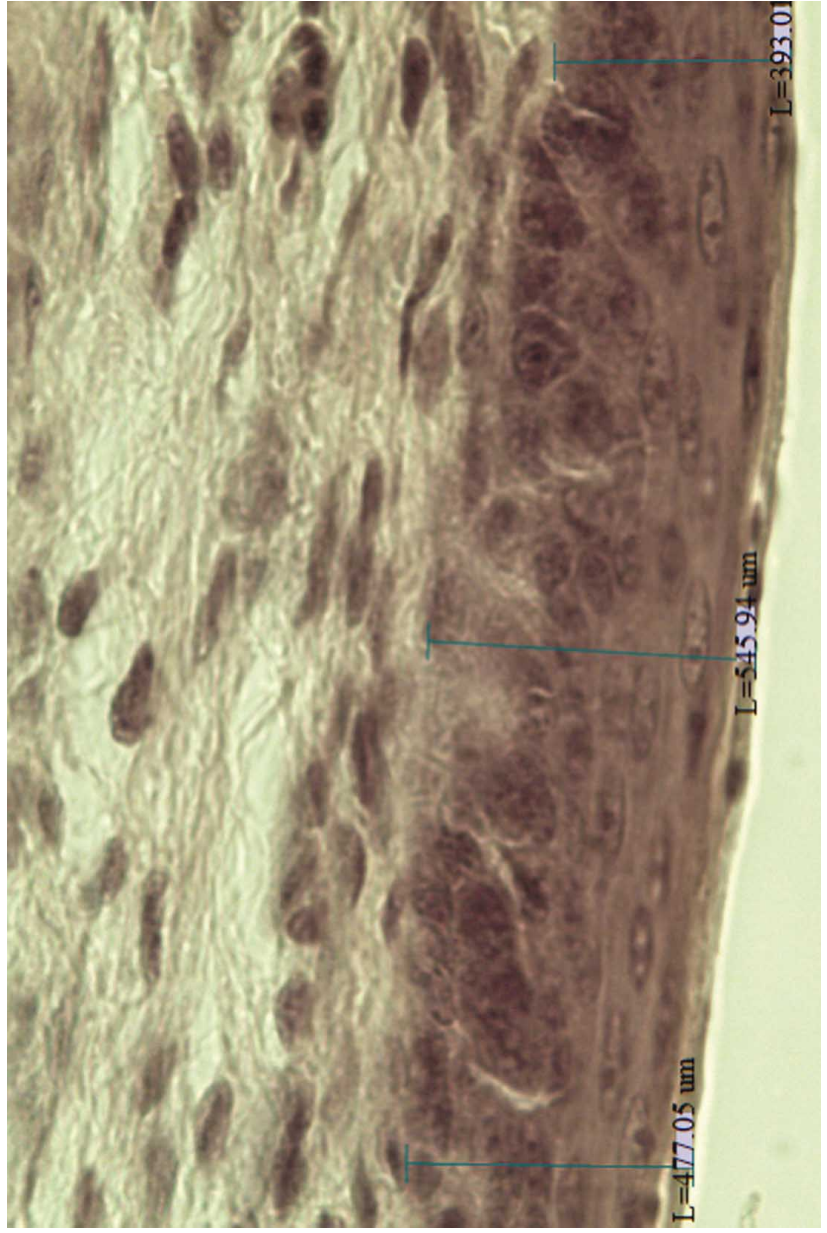

Fig. 1. Microphotography of the vocal fold mucosa of one Sham group subject. Observe the epithelial thickness measurements made at three points of the image (H-E 40X).

\section{DISCUSSION}

Human laryngeal tissues have a significant number of sex steroid receptors (Newman et al., 2000; Claassen et al., 2006), suggesting an effect of these hormones in phonatory function (Mendes-Laureano et al., 2006). Through the investigation on the epithelium covering the vocal folds, the effect of induced menopause in an animal model was determined. Our results indicate that there are alterations in the number of cell layers that constitute the epithelium and in features, such as cellular cohesion and increased extracellular matrix that result in epithelial thickening. As a result of the decreased number of cell layers in the epithelium of the human vocal fold, an increase in the extracellular space and an increasing water level in the epithelium were observed, making the fold more edematous. The mucosal wave vibration can be decreased in frequency, and the amplitude increased,

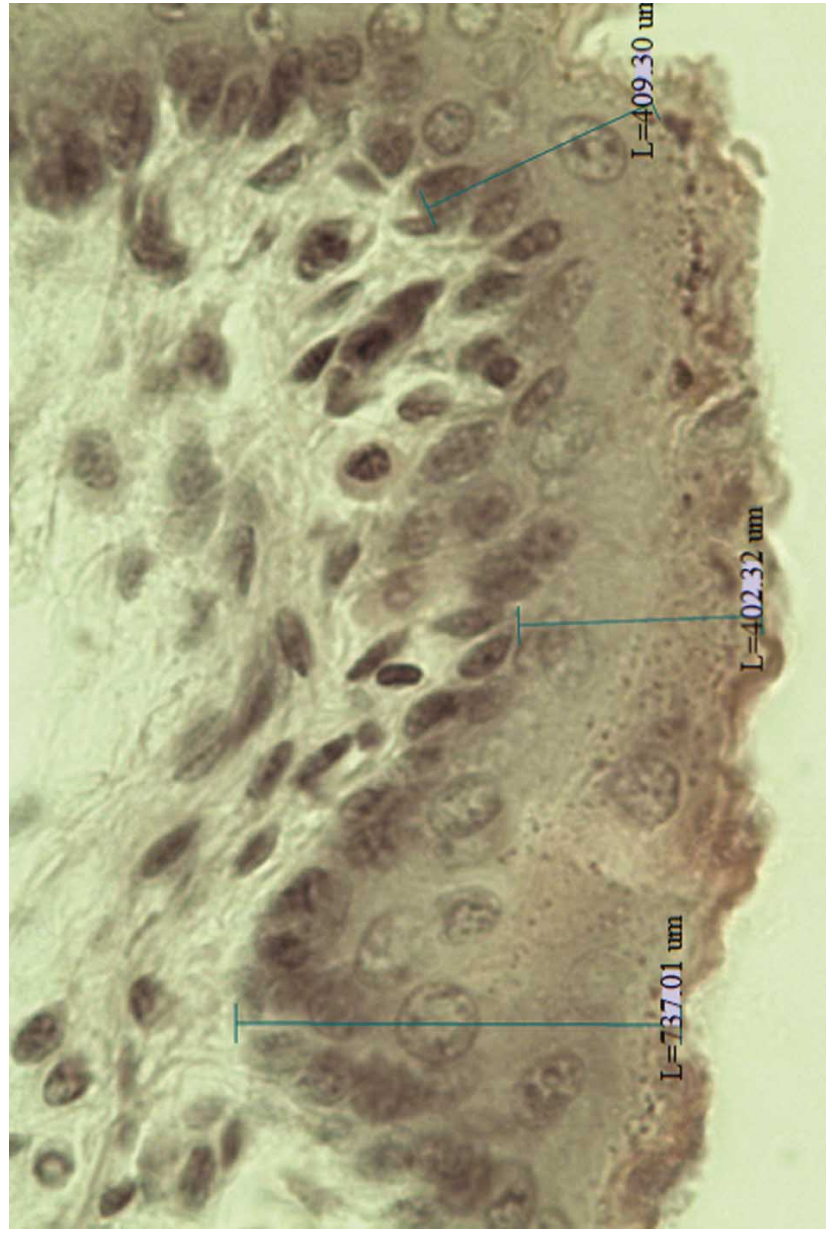

Fig. 2. Microphotography of the vocal fold mucosa of one OVX group subject. Observe the epithelial thickness measurements made at three points of the image (H-E 40X).

explaining the drop in fundamental frequency, pitch shift to the bass, and treble loss in postmenopausal women (Aponte, 2003).

Recently, Surmeli et al. (2010) similarly evaluated the changes induced by menopause in an animal model. Using groups that underwent oophorectomy and SHAM surgery, these authors reported significant changes 4 weeks after oophorectomy, such as inflammation, subepithelial edema, and decreased goblet cells. These findings are consistent with our results and suggest that alterations of the laryngeal mucosa are of epithelial-connective origin.

Although this study has the limitations of an animal model, such as clinical correlation of the findings, a decrease in cellular layers and number of epithelial cells, 
which affects the function of the epithelium as a hormone receptor, was reported. On the other hand, changes in cell morphology and lack of cell nuclei in the outer layer of the epithelium could alter the role of this layer in producing mucus, which is responsible for maintaining hydration and protecting the adjacent structures, which is associated with less lubrication of the vocal folds, resulting in more roughness and hoarseness of the voice (Schneider et al., 2004).

According to Kiliç et al. (2004), the main changes of the vocal folds of postmenopausal women were edema, thickening, and hyperemia related to declining estrogen levels. Raj et al. describe the vocal menopause syndrome, characterized by low vocal intensity, vocal fatigue, decreased range, high-tone loss, loss of voice quality, vocal dysfunction and distress, lower voice frequency, increased roughness, and hoarseness.

In this research, the preliminary evidence of changes experienced by the mucosal epithelium of the vocal folds due to the deprivation of female hormones was presented. Therefore, it is necessary to develop clinical research on which of the therapeutic measures used by postmenopausal women contributes more to the stability and health of this tissue and its effectiveness, for a better understanding of the role of the mucosal epithelium of the vocal folds on voice quality.

OYARZÚN, P.; SEPÚLVEDA, A.; VALDIVIA, M.; ROA, I.; CANTÍN, M.; TRUJILLO, G.; ZAVANDO, D. \& SUAZO, G. I. Variaciones del epitelio del pliegue vocal en un modelo de menopausia inducida. Int. J. Morphol., 29(2):377-381, 2011.

RESUMEN: Durante la menopausia ocurren cambios en las estructuras laríngeas que tienen implicancias en la voz. El objetivo de este estudio es determinar el efecto de la menopausia inducida sobre parámetros morfológicos de la mucosa de los pliegues vocales en ratas de laboratorio. Se analizaron 10 ratas Sprague-Dowley hembras adultas, divididas en dos grupos, 5 fueron ooforectomizadas quirúrgicamente (OVX) y 5 fueron sometidas a un procedimiento SHAM (SHAM). Luego de 30 días postcirugía, se observaron las características del epitelio del pliegue vocal, en términos de disposición celular y organización del epitelio. Adicionalmente con la ayuda del software Morphometrics XS se determinó la altura del epitelio y la densidad de número de estratos celulares. Nuestros resultados indican que existen alteraciones en número de estratos celulares, así como también en características como cohesión celular, acompañado de un aumento de la matriz extracelular. El número de estratos celulares fue significativamente mayor (p<0,01) en el grupo SHAM con 6,66 (DS 1,07), mientras que en el OVX fue de 3,2 (DS 0,83). El grosor medio del epitelio fue de 534,71 $\mu$ m (DS 119,89), mientras que en el grupo SHAM fue de 486,84 $\mu \mathrm{m}$ (DS 82,95), estas diferencias no fueron estadísticamente significativas ( $\mathrm{p}=0,112)$. Se sugiere que alteraciones en las características del epitelio que reviste los pliegues vocales pueden relacionarse con alteraciones clínicas como la disminución de la calidad vocal y la presbifonía características de la mujer postmenopáusica.

PALABRAS CLAVE: Pliegue vocal; Voz; Menopausia; Ooforecomía.

\section{REFERENCES}

Aponte, C. Evolución de la voz desde el nacimiento hasta la senectud. Acta de otorrinolaringología y cirugía de cabeza y cuello, 31(2):1-7, 2003.

Claassen, H.; Mönig, H.; Sel, S.; Werner, J. A. \& Paulsen, F. Androgen receptors and gender-specific distribution of alkaline phosphatase in human thyroid cartilage. Histochem. Cell Biol., 126(3):381-8, 2006.

Cingolani, E. \& Houssay, A. Fisiología Humana. $7^{\text {a }}$ edición. Buenos Aires, El Ateneo, 2000. pp.716-7.

Delgado, C. La identificación de locutores en el ámbito forense. Tesis Doctoral, Facultad de Ciencias de la Información, Madrid, Universidad Complutense de Madrid, 2001.
Gutiérrez, C. Evolución de la voz desde el nacimiento hasta la senectud. Acta de otorrinolaringología \& cirugía cabeza y cuello, 2(3):4, 2003.

Kiliç, M. A.; Og üt, F.; Dursun, G.; Okur, E.; Yildirim, I. $\&$ Midilli, R. The effects of vowels on voice perturbation measures. J. Voice, 18(3):318-24, 2004.

Mayo, J. A natural Approach to Menopause. ANSR, 7(5):18, 1999.

Mendes-Laureano, J.; Sá, M. F.; Ferriani, R. A.; Reis, R. M.; Aguiar-Ricz, L. N.; Valera, F. C.; et al. Comparison of fundamental voice frequency between menopausal women and women at menacme. Maturitas, 55(2):1959, 2006. 
OYARZÚN, P.; SEPÚLVEDA, A.; VALDIVIA, M.; ROA, I.; CANTÍN, M.; TRUJILLO, G.; ZAVANDO, D. \& SUAZO, G. I. Variations of the vocal fold epithelium in a menopause induced model. Int. J. Morphol., 29(2):377-381, 2011.

Newman, S. R.; Butler, J.; Hammond, E. H. \& Gray, S. D. Preliminary report on hormone receptors in the human vocal fold. J. Voice, 14(1):72-81, 2000.

Santos, W. V.; Pereira, L. M. \& Mandarim-de-Lacerda, C. A. The effect of enalapril on the cardiac remodelling in ovariectomized spontaneously hypertensive rats. Int. J. Exp. Pathol., 85(5):287-94, 2004.

Schneider, B.; Van Trotsenburg, M.; Hanke, G.; Bigenzahn, W. \& Huber, J. Voice impairment and menopause, Menopause, 11:151-8, 2004.

Sheehan, D. C. \& Hrapchack, B. B. Theory and Practice of Histotechnology. $2^{\text {nd }}$ ed. St. Louis, Mosby, 1980. pp.196-7.

Storck, S. Menopause. U. S. National Library of Medicine, 2009. Avalaible in: http://www.nlm.nih.gov/ medlineplus/ency/article/000894.htm

Surmeli M, Habesoglu TE, Habesoglu M, Deveci I, Eriman M, Kinis V, Gunes P, Egeli E. Histopathological effects of estrogen deficiency on larynx mucosa in ovariectomised rats. Eur. Arch. Otorhinolaryngol., $2010 \mathrm{Jul}$ 18. [Epub ahead of print]

Torres, B. Anatomía funcional de la voz. Medicina del canto. Capítulo 1, 2007. Avalaible in: http:// www.medicinadelcant.com
Correspondence to:

Prof. Dr. Iván Suazo Galdames

Morfología

Avenida Lircay s/n oficina $N^{\circ} 104$

Universidad de Talca

CHILE

Phone: 56-71-201682

Email: isuazo@utalca.cl

Received: 07-01-2011

Accepted: 12-03-2011 